Article

\title{
Spatio-Temporal Database of Places Located in the Border Area
}

\author{
Albina Mościcka * (iD) and Marta Kuźma \\ Faculty of Civil Engineering and Geodesy, Military University of Technology, 00-908 Warsaw, Poland; \\ marta.kuzma@wat.edu.pl \\ * Correspondence: albina.moscicka@wat.edu.pl
}

Received: 18 January 2018; Accepted: 12 March 2018; Published: 14 March 2018

\begin{abstract}
As a result of changes in boundaries, the political affiliation of locations also changes. Data on such locations are now collected in datasets with reference to the present or to the past space. Therefore, they can refer to localities that either no longer exist, have a different name now, or lay outside of the current borders of the country. Moreover, thematic data describing the past are related to events, customs, items that are always "somewhere". Storytelling about the past is incomplete without knowledge about the places in which the given story has happened. Therefore, the objective of the article is to discuss the concept of spatio-temporal database for border areas as an "engine" for visualization of thematic data in time-oriented geographical space. The paper focuses on studying the place names on the Polish-Ukrainian border, analyzing the changes that have occurred in this area over the past 80 years (where there were three different countries during this period), and defining the changeability rules. As a result of the research, the architecture of spatio-temporal databases is defined, as well as the rules for using them for data geovisualisation in historical context.
\end{abstract}

Keywords: spatio-temporal database; geographical names; geovisualisation; border area

\section{Introduction}

The concept of telling a story is related to the relationship between story expression, and the broader context within which the story is presented and interpreted [1,2]. One of them may be the geographical context, and storytelling in this context is a human experience in geographical space, understood as the relations between people, things, events, and places. The first solution used to tell stories in geographical space were maps. They have always been valued because they provide a large amount of detail in a small amount of space. Telling stories through maps began with describing explored lands in great detail. Today, many sources providing data about people, events and places, which were formerly used and examined only by geographers and other earth and environmental scientists, are in the hands of the general public. Such datasets together with geographic tools and multimedia expand the ability for storytelling through maps and have greatly multiplied the attraction that maps have had for centuries to tell stories [3].

In the digital age, storytelling with maps was mainly based on historical events or objects presentation on digital maps [4], as well as the development of historical GIS [5-7]. At the same time, the limitations of traditional solutions in this area resulted in the development of spatio-temporal databases, which are a source of data used for storytelling. There are a lot of considerations and research on possible spatio-temporal changes a geographic object [8,9], spatio-temporal data integration and querying [10,11], spatio-temporal data models [12,13], as well as spatio-temporal database management [14].

Today, that mode of understanding stories and storytelling has reached a kind of a limit. The intellectual, political, and empirical contexts within which stories were placed is starting to 
be replaced by practice, materiality, embodiment, affect, ontology, and knowledge discovery [15-17]. This is the result of the process of digitization of huge data sets and the development of visualization methods, which created new opportunities for storytelling. So far, the most attention, time and money have been devoted to the process of obtaining data, creating databases, etc. Currently, the time has come to disseminate them, exchange them between institutions, as well as to use data collected in different resources, exploring knowledge hidden in them and their attractive presentation. These challenges create the needs for the modification, correction of achievements in the field of data acquisition, and development of new methodologies, dedicated to the wider use of collected data, and not just to owning them in a digital form.

As it was already mentioned, storytelling requires both a story and its context. Story presentation in geographical space requires thematic data (data about story), as well as background data (data about geographical context) [18] and both these types of data can vary over time. It needs to be highlighted that spatio-temporal databases developed so far were mainly related to a single topic and its variability over time related to thematic data [19-21]. Therefore, the objective of the article is to discuss the concept of spatio-temporal database as a resource of background data for thematic data visualization in time-oriented geographical space. This research is the result of immutability of geographical localization but variability of geographical space attributes. Geographic information is this kind of element to which the past can refer to and which remains unchanged for centuries. It means that independently from changes in borders and political affiliations a place in space (defined by coordinates) still remains the same. But, people, things, places, or events described in stories can refer to places that no longer exist, have changed their names, or lie outside the current boundaries of the country, because they have changed in the meantime. It means that some attributes of geographical space can be changeable over time and to understand a story we need to present them in their geographical and historical context at the same time. Moreover, a story can be presented in different semantic geographic contexts [22], providing a possibility of data analysis and visualization in various aspects. Telling the story about the past meets the problem, which geographical background should be used to present information related to the past. What if there is a need to refer to the old or present space depending on the situation? This problem is all the more complex when it concerns border areas, where political changes result in changing the nomenclature to a different language, often written in a different alphabet and the analyzed events or phenomena are located in the territory of a few countries. In such cases, a transnational cooperation seems to be the key to effective research as it can result in effective understanding of the past as well as of the future development of cross-border regions. There are more than 70 cross-border regions in Europe today. An increasing number of cross-border co-operation initiatives has been presented in form of case studies in subject literature. Numerous authors have produced a wealth of work in various disciplines such as geography, political sciences, international relations, administrative sciences, and sociology. Their background of the history as well as the conceptual definition of their various forms and positions have been described by Perkmann [23]. He also discusses the geographic distribution and development of cross-border regions over time and presents the European Union (EU) policies that support them. Several models of cross-border cooperation were presented by Medeiros [24]. He describes cross-border typology that looks at the concept of Euroregions from a geographical point of view. He analyzed eight European sub-regions and concluded that, in all of them, some administrative and institutional barriers still exist. These barriers interfere, among others, with the common use of social infrastructure. The European Union stimulates institutional and administrative cross-border cooperation through such programs, as, for example, INTERREG, which supports and promotes integrated regional development also in neighboring border regions, including regions located at the external borders of the EU. The INTERREG community initiative is also the creator of new European regions [25] and it provides evidence that this initiative strengthened the foundations for building structures designed to stimulate the process of cross-border cooperation. This cooperation often emerges in a bottom-up way, initially in response 
to shared urgent planning problems. Only as the awareness and subsequent needs develop, will it be incorporated into the official programs and policies and become institutional [26].

Bottom-up cross-border initiatives are the starting point for cooperation also in geographical, cultural, and historical research. Therefore, telling stories is not the only research motivation of the presented study. Spatio-temporal databases of places located in the border area can have several others possible application fields. One of them is to use spatial information (coordinates of place location) as an integrator of different kind of data as well as spatially-oriented cultural goods, which are referred to the common past of the neighboring countries, in a single common space. The information needed for interdisciplinary research is typically distributed over a vast range of domains, formats, and languages, reflecting the many different perspectives to be considered [27]. Integration of such data is the key point to obtain complete knowledge about the studied area, regardless of the political affiliation of each part of this area, and to conduct effective cross-domain research. In a situation where many researchers thought that at least $60 \%$ (some of them think that even $80 \%$ ) of information is geospatially referenced [28], spatial information seems to be a powerful integrator [29]. This is also particularly important in the case of movable heritage (e.g., archival documents), which is currently collected in thousands of cultural institution and databases scattered around the world. These monuments can be created in one place, but now they may be stored at an entirely different location, often outside the country of creation. Moreover, their content can be related to still other places, different from their place of origin or storage. This is due to the fact that movable monuments can be easily moved from one place to another, so their reference to geographical space is not unambiguous, as it can be changed over time. The descriptions of such monuments (in metadata), usually do not use coordinates. They are referred to places with which the monument is connected by the names of the town. However, these names can be changed, especially in border areas. This leads to situations when the description of the given archival document refers to a locality name used at the time when the document was created, the present name (in the language of the country where the place is currently located), or many other forms of names. Linking different forms of a name with geographic information can solve this problem, because information about location-as defined by geographic coordinates, not political membership-unambiguously defines a place in space.

To at least partially minimize this problem, lists of geographic place names and their coordinates, called gazetteers are created. However, they are usually limited to the territory of one country [30] (they contain names from one country area (in present borders) [31], and even if they have old names, they are not related to the time when they were valid [32]. This problem may be solved by the spatial database containing geographical objects (places) with names changing in time if we find the answer to the research question: what structure it should have in order to be used for thematic data visualization in time-oriented geographical space and how it can be used in practice. Answering the above questions by proposing practical solutions in this area results in the contribution to the research on variable geographical background as a valuable context for telling stories.

\section{Materials and Methods}

The basis for the methodology used was the fact that geographical space changes over the years. The natural elements change the slowest (or not at all), while the anthropogenic elements change faster. Together, they enable us to understand the topographical conditions of many phenomena. But the most important elements enabling us to orient ourselves on maps unambiguously are names-names of localities, rivers, regions, etc. Therefore, it was assumed in the research that to understand the context of historical thematic data (e.g., events, phenomena), they should be presented on the background in which they originally emerged, i.e., the historical background. What is more, it was established that the automation of mapping processes or other geo-visualizations of the past creates now premises for developing solutions that allow for the presentation of past phenomena in the past or present space, a combination of both, and the multiple use of elements of historical space to visualize various and independent thematic phenomena from that period. It was assumed that the key point of this 
solution is a spatio-temporal database that contains places in such form as existed in each period of time. In addition, the structure of the database should enable recording data about localities whose names can occur in different forms and languages. Moreover, in some periods, recorded names can occur in different languages on different parts of the analyzed region. Such situation happens when the historical territory of one country has been divided and is currently located in several countries. Therefore, the basis for the database development was to define the rules for the changeability of names over time and periods in which they happened.

Taking the above into consideration, it was assumed that, in order to define each place that is located in the border area in the database, three components of the given place should be defined: location, time, and an array of attributes. As some of these attributes are changeable over time, it was established that each place should be represented in the database by simultaneous states of the object (object instance), i.e., its location with names in distinct periods of time. Within the given time period, the position and attributes of the place are to be defined. Due to the complexity of research at this stage, the focus was only on the variability of attributes (names), assuming the immutability of the location of a given locality (Figure 1).

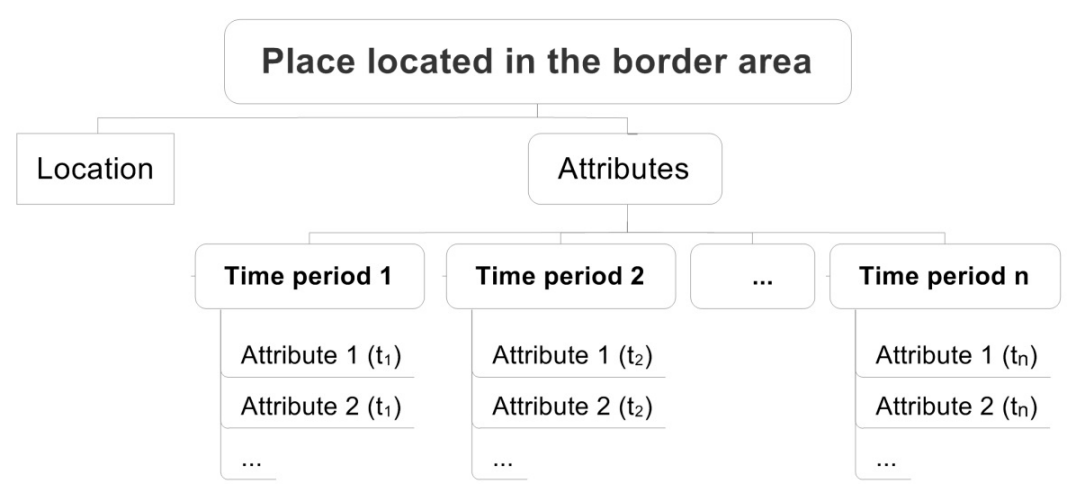

Figure 1. The idea of representing the place by means of simultaneous states (source: own study).

The proposed structure of spatio-temporal database will enable to visualize historical thematic and background data according to user needs and expectations, as well as to the specificity of data changeability. The established solutions are presented in Figure 2.

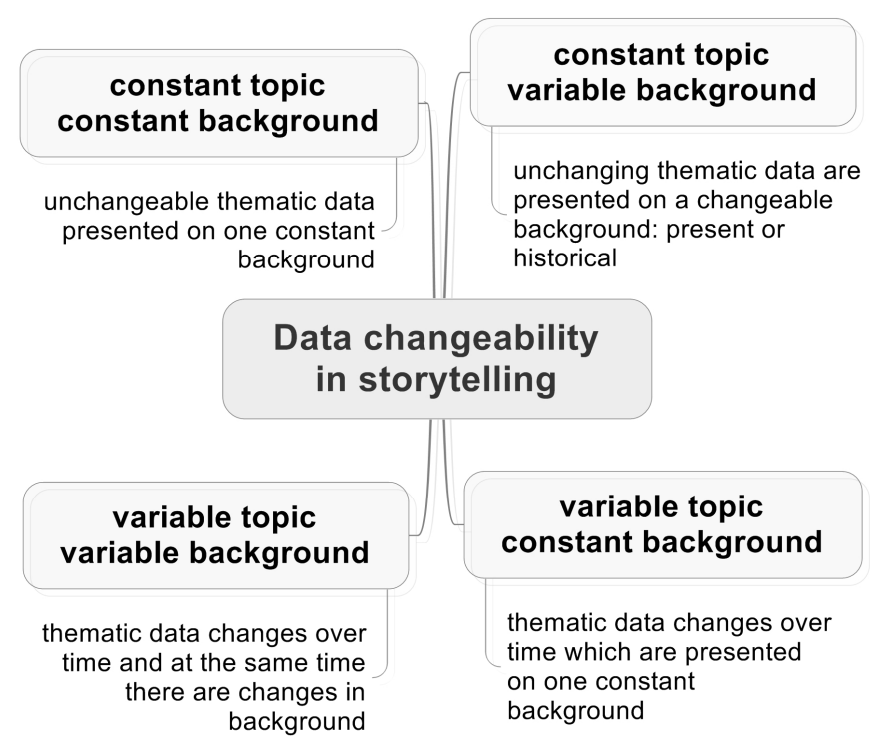

Figure 2. Possible combination of thematic and background data presentation (source: own study). 
The research was supported by a case study focusing on studying the place names on the present Polish-Ukrainian border. Before the Second World War (until 1939), the analyzed area was the part of Republic of Poland with the official Polish language. After the Second World War, there have been major changes in the location of the political border and the analyzed region was divided into two parts. The first one, i.e., the western part, remained in Poland, while the eastern part became a part of the Soviet Union as the Ukrainian Socialist Soviet Republic (USSR) with the official Russian language. In 1991, on the eastern part, the independent Ukrainian state was established with the official Ukrainian language. Between 1939 and 1945, this area has passed from Russian to German hands several times, but these changes, due to their frequency and short duration (without new maps development), were not included in the studies. The timeline presenting the changes on the eastern part of the test area is shown in Figure 3. The location of the contemporary Polish border and of the border before World War II is shown in Figure 4.

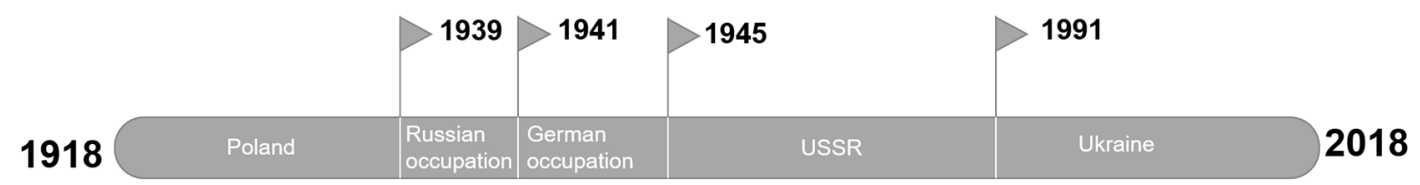

Figure 3. Timeline presenting the changes on the eastern part of the test area (source: own study).

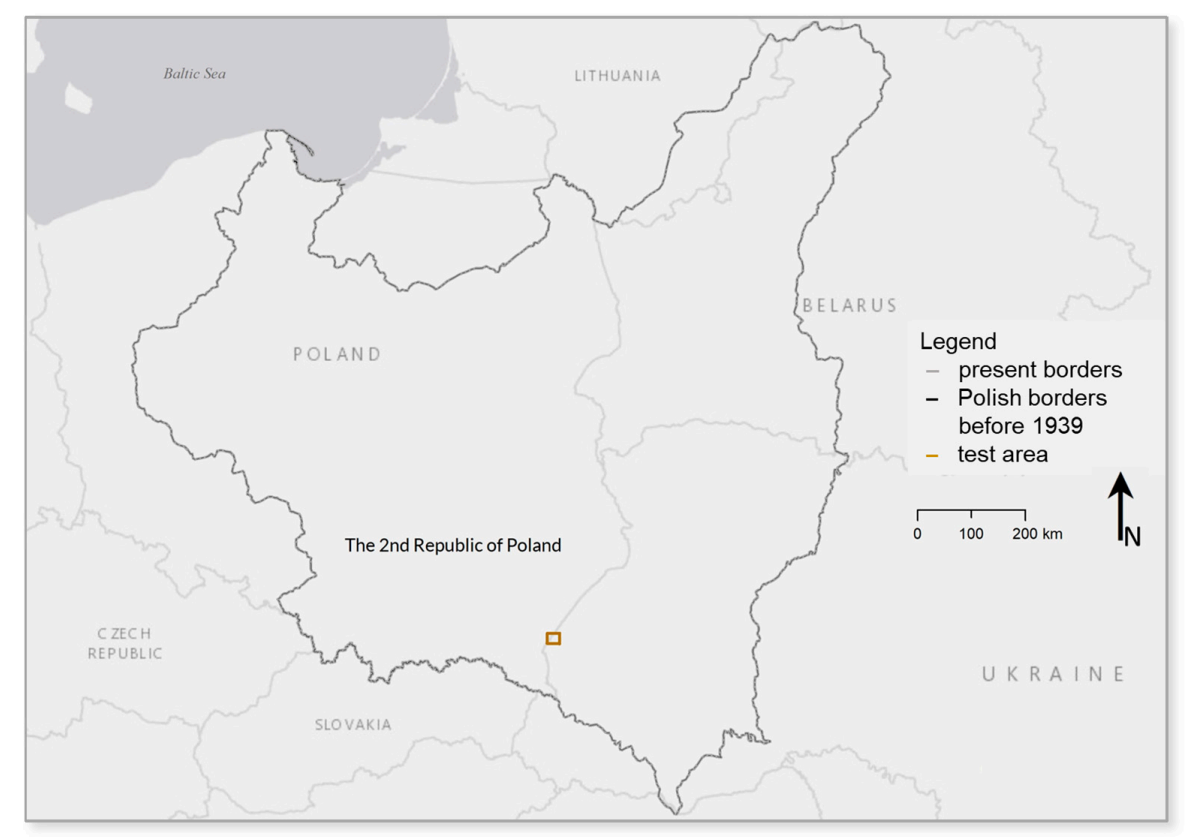

Figure 4. Borders in different time periods: light grey—present borders, dark grey-Polish border before 1939 (Second Republic, in Polish: the Second Republic-II Rzeczpospolita), small brown rectangle-test area (source: own work).

Changes in statehood were associated with profound changes in the names of towns and villages in the analyzed area. They concerned both changes in the language used for names as well as other changes in names. To analyze the changes, three different maps in different languages and related to different time periods were used. It was assumed that the first stage of the undertaken research should be directed to the local level, since most documents or events related to these areas are referred to names in languages that were in force in that area. Therefore, as the basis for the selection of maps for analyzes was the assumption that maps for different periods should contain names in that language that was valid in each part of the test area during a given period. Therefore: 
- a map in Polish was selected to obtain names for the whole area for the pre-war period;

- a map in Russian was selected for 1945-1991 to obtain names for that part of the area that became part of the Soviet republic after the war; and,

- a contemporary map with current names in Ukrainian and Polish was selected to obtain Ukrainian names for the Ukrainian part of the test area and to update the present Polish names for the currently Polish part of the test area.

The Russian map and OSM (Open Street Map) for Ukraine were used to obtain names from the area that currently lies outside of Poland. OSM data for Poland was necessary to check if there are any changes in Polish names in comparison to the pre-war map. Despite the fact that at the end of the nineties there was a large administrative reform in Poland, its effects did not affect the examined towns, as it concerned only the administrative division, not the place names. In the research undertaken, towns are not located with regard to the administrative division, which is variable over time, but to the coordinates that guarantee the immutability of the location of the town. This approach creates reasons to minimize the impact of factors that are known to be often volatile, even within one country. Furthermore, it was also assumed that the database should be designed so as to enable its development adding other names e.g., in English.

Finally, the following maps were selected for testing:

- topographic map of Military Geographic Institute (Wojskowy Instytut Geograficzny-WIG) in 1:100,000 scale, timelines on 1934 (sheets: P49 S35, Przemyśl, edition 1937; P49 S36, Mościska, edition 1938; P50 S35, Dobromil, edition 1938; P50 S36, Sambor, edition 1937)—the source of Polish names before 1939;

- topographic Russian map in 1:200,000 scale, timelines on 1970 (sheets: M-34-XXIII, Przemyśl, edition 1978; M-34-XXIV, Drohobycz, edition 1974)—Russian names used between 1945-1991; and,

- Open Street Map with present localities names for both Polish and Ukrainian parts of the test area—current Polish and Ukrainian names (used since 1991).

Polish, Russian, and Ukrainian names were selected for 660 places of different types: cities, villages, localities, suburbs, towns, hamlets. These places are located in Podkarpackie voivodeship, near Przemyśl and Radymno as well as in Lviv Oblast, near Краковець, Мостиська, Добромиль, Самбір, Новий Калинів.

Comparative and empirical research methods were used in order to develop rules for the changeability of names. Comparative methods were used to compare places in different time periods. The aim of the comparative studies was to determine similar or identical characteristics and features that distinguish the compared names (other than those resulting from the change of language). According to the comparative method rule, "not to compare too many features at once", the number of compared name forms was limited to three languages and three time periods. Names were treated as dependent variables, which can be changed into other language on the basis of phonetics or letter spelling. Some of the names can be independent variables when they are changed into a completely different form. The starting point of the research were Polish pre-war names, as they were used in the whole testing area and they were in the native language of the authors. First, the Russian names were compared in relation to Polish ones. Then, Ukrainian names were checked in relation to Russian ones. Some limitations of the comparison have also been defined, mainly for places that do not occur on some maps. The main area of focus were the directions of changes, i.e., the classification of the changeability rules into main groups rather than defining detailed rules for each specific change.

Empirical methods were applied to determine the elements of places description in the database. The localities attribute content and basic structure of the database were defined with use of brainstorming and idea reduction methods. In the first stage, as many name features and solutions related to the database architecture as possible were collected. Next, those ideas that were not worthy of further discussion, were canceled. They were related e.g., to the attributes whose values were 
impossible to collect on the basis of maps, as well as solutions that did not offer the possibility to extend the number of place names or new simultaneous states in the future. Ideas that were not rejected were prioritized into these that could be realized (and complete the database) on the basis on the test dataset and those that needed further research. On the basis on this selection the examples of the content of simultaneous states and prototypes of database architecture were defined. Drawing sketches of results were used to support the development of the final concept of spatio-temporal database structure, as well as its use for historical data presentation. A formal description of the arrangements was prepared using object-oriented modeling UML (Unified Modeling Language).

\section{Results}

The whole analyzed area had been located in Poland before World War II, but as a result of political changes it was divided into two parts. The western part remained within the borders of Poland, while the eastern part was incorporated into the Ukrainian Socialist Soviet Republic, and then transformed into the Ukrainian state. These political changes are reflected in the results of the study of the names of localities in this area. These results demonstrate that name changes in the test area can be divided into two main groups. The first group includes names in the current territory of Poland. These are names that were not subject to changes as a result of changes in political boundaries in the analyzed period, but only as a result of the internal changes in Poland. The second group of names are the names located in the eastern part of the test area and they have changed the most.

As a result of the methodology used, the rules of name variability were defined. They were analyzed by comparation of WIG and OSM maps for Polish part of the test area (Table 1) and in three variants for the Ukrainian part of the test area: conversion of Polish names into Russian, conversion of Polish names into Ukrainian, conversion of Russian names into Ukrainian (Table 2). As a result of the analysis, it was noticed that changes that took place in the Polish territory consisted mainly in abbreviation or elongation, while the main ways used to create names in different languages (Ukrainian territory) were transliteration and transcription.

Table 1. Changes of Polish names (source: own study).

\begin{tabular}{ccc}
\hline Rules & Number of Objects & Example \\
\hline All & 215 & - \\
\hline The same name & 177 & $\begin{array}{c}\text { Dmytrowice-Olszynka } \\
\text { Other name }\end{array}$ \\
\hline Abbreviation & 25 & $\begin{array}{c}\text { Parcelacja Boratyn-Parcelacja } \\
\text { Makowa Rustykalna-Makowa }\end{array}$ \\
\hline Elongation & 9 & Widna-Widna Góra \\
\hline Does not exist & 4 & Stary Kalinów \\
\hline
\end{tabular}

Using transliteration, names originally written with the characters (letters) of one phonetic letter were converted using the characters (letters) of another phonetic letter. It was based on the strict correspondence of letters: one letter (or a fixed group of two or more letters) of a given letter system corresponds to one and the same letter (or group of letters) of the second system. Transliteration enabled the reproduction of the original record, which is usually not possible in the case of phonetic transcription.

The most number of names have been changed using transcription. It was based on saving the sounds of a given language using graphic symbols (phonetic spelling). It was used to write the words of one language in a form that allows for easily reproducing the sound to the person who does not know it- the sounds of one language were written using the signs of another language, but a given sound may not always correspond to only one sign, and some signs can be used to mark several 
different sounds in the output language. Through transcription, one hundred Polish names have been changed into Russian. Main rules of changes were based on:

- exchanging ,-се", ,-ісе", „-усе”, „-усzе" for „--цы”, „-ичи", „-ицы”, „-ычи" (51 names, e.g., Tamanowice-Тамановичи);

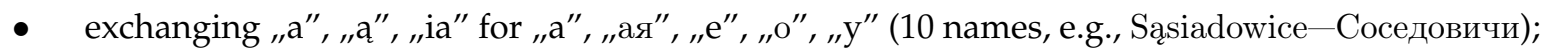

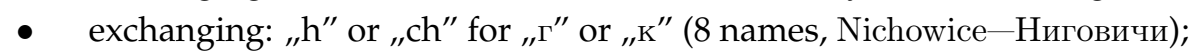

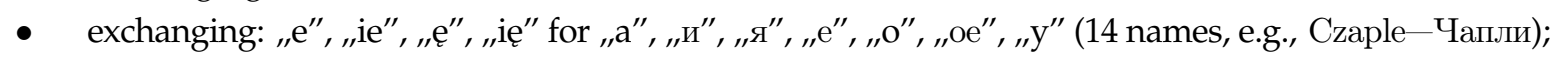

- exchanging: „i" , „y" for „, $\mathrm{e}^{\prime \prime}$, , $\mathrm{a}$ " (3 names, e.g., Tyrawa-Tарава); and,

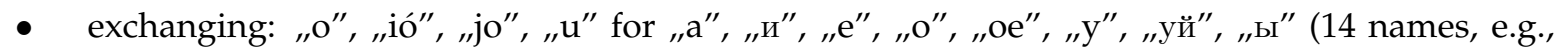
Bonów-Бунов).

Using transcription, 86 Russian names have been transformed into Ukrainian. As these languages are really similar, only few rules have been used:

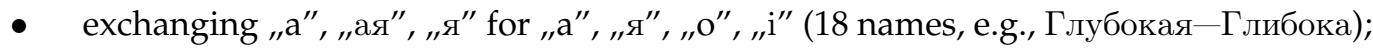

- exchanging ", $\mathrm{e}^{\prime \prime}$ for "i", , ,я" (22 names, е.g., Заречье-Заріччя); and,

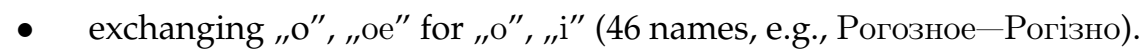

It is worth to pay attention to the proximity of Polish and Ukrainian names. 124 Ukrainian names have forms consistent with their transcription from Polish. Main rules of changes were based on:

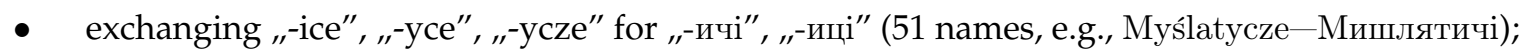

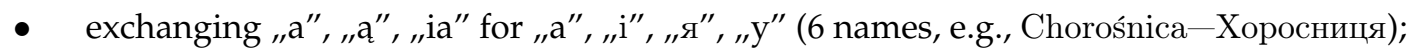

- exchanging „„ów”, „ówka” for „ів”, „івка" (14 names, e.g., Berezów-Березів);

- exchanging "h" or "ch" for ", $\mathrm{F}^{\prime \prime}$ (10 names, e.g., Michowa-Мігово);

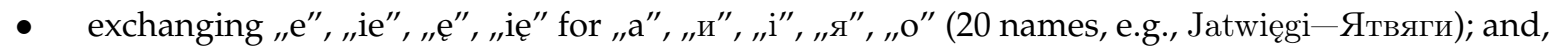

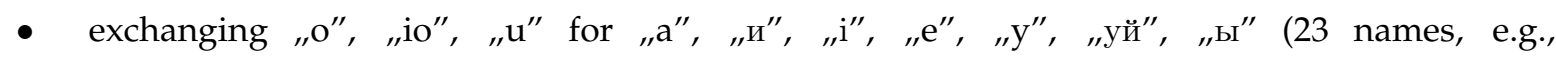
Wojkowice--Вуйковичі).

As the result of the analysis of places and their names, it was also noticed that changes are not only related to changing the form of the names. Moreover, these rules are related to both parts of the test area: Ukrainian and Polish one and they can be classified into the following groups of localities:

- localities that have changed their status, when e.g., a village became a town (e.g., pre-war Rudno is now town called Рудня);

- localities which arose as a result of connecting two neighboring localities and creating a new one with a new name (е.g., Новий Калинів, which was created from the merged of two villages Kalinów and Stary Kalinów and received a new name);

- suburban localities that have disappeared as a result of their inclusion into the neighboring town (e.g., the pre-war village Posada is currently a part of neighboring town Хирів); and,

- localities that have disappeared as a result of e.g., peoples displacement and no longer exist.

The above cases result in a different number of names registered in each time period. An example of such changes is presented in Figure 5.

Taking into account the variability of place in time, as well as the possibility of presenting the collected cities with names depending on the user needs and expectations, a time-space database of localities was developed. This architecture of the database is presented in the form of a class diagram in UML language (Figure 6). Each simultaneous state is defined by the set of locality attributes that characterized them in the selected time period. The range of attributes, as well as the number of states can be extended depending on the user's needs. Formal description of the database structure allows for implementing the structure in any database environment. Implementation of the database in ArcGIS is 
presented in Figure 7 and simultaneous states of the selected locality (instances) are shown in Figure 8. They present sets of attributes of the same locality in each analyzed time period (before 1939, 1945-1991, after 1991). The proposed database structure can be used to present thematic phenomena with the present or historical background, according to user needs and expectations. It has been assumed that storytelling demands both: background and thematic data. Background data, taken from the spatio-temporal database, may contain places with present, historical, or mixed names. Practical use of the database consists in selecting one (or several) simultaneous states of places in a given time period and presenting it as background data. The examples of different variants of the background generated from database are presented in Figures 8 and 9. These variants of background can be used depending on what kind of thematic data is available. According to the rules presented in Figure 2, this may be thematic data that changes over time or not. If it is related only to one time period, then a background presenting names from only one time period (1937 or 1978 in the Figure 9) can be used. Such data can be also related to the present background (2017 in the Figure 9), especially if we need to relate past events into the present space. The other solution is to use historical names together with present names on the background map (2017/1937 or 2017/1978 in the Figure 9). If thematic data changes over time, it means that it is related to at least two different time periods. In such cases, the effective solution consists in using the combination of two (1978/1937 in Figure 9) or even three names (2017/1978/1939 in Figure 9) for each locality. Preparing maps with the use of proposed database provides unlimited possibilities of background design, which is the most important in border areas, where the names that are used are in different languages, depending on the time period. Placing thematic data into such background locates thematic data in the political context, which can be essential to understand the presented story.
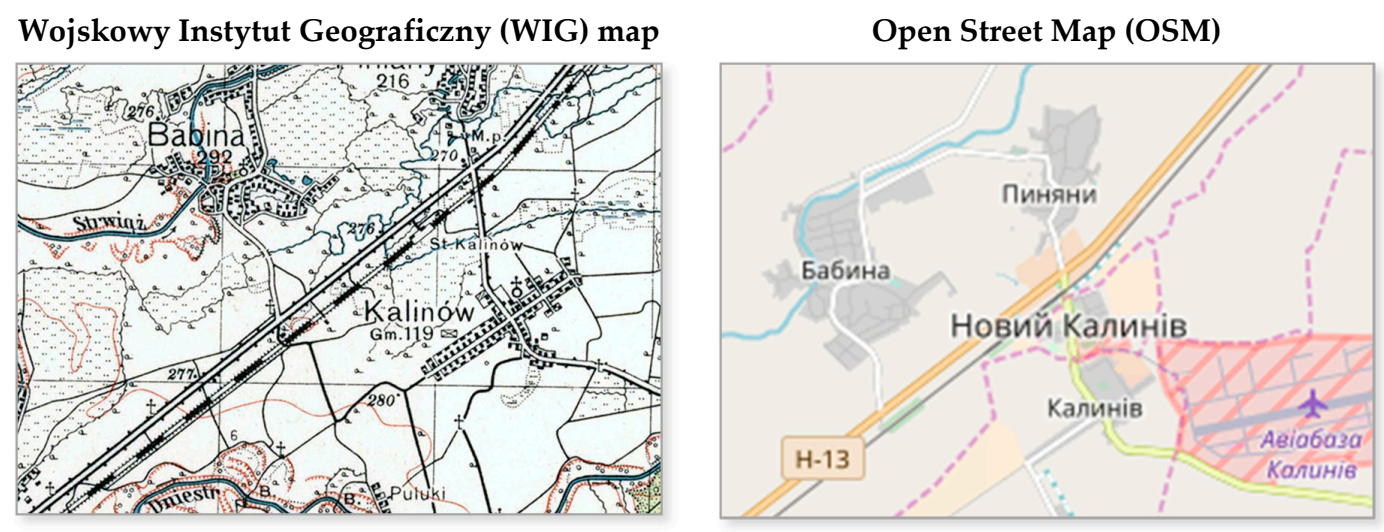

Figure 5. Connection of localities under a new name (source: WIG map, Russian map, and OSM). 
Table 2. Rules for naming variations between Polish, Russian, and Ukrainian names (source: own study).

\begin{tabular}{|c|c|c|c|c|c|c|}
\hline Language of Changes & $\begin{array}{c}\text { Total Number } \\
\text { of Objects }\end{array}$ & $\begin{array}{c}\text { The Same } \\
\text { Name }\end{array}$ & Other Name & Transliteration & Transcription & Undefined \\
\hline Polish into Russian & 222 & - & $\begin{array}{c}35 \text { objects } \\
\text { Examples: } \\
\text { Porudno-Калиновка } \\
\text { Słomianka-Хоросниса } \\
\text { Lacko-Соляноватка }\end{array}$ & $\begin{array}{c}85 \text { objects } \\
\text { Examples: } \\
\text { Zabłotce--Заблотце } \\
\text { Tapin-Тапин } \\
\text { Lutków-Люткув }\end{array}$ & $\begin{array}{c}100 \text { objects } \\
\text { Examples: } \\
\text { Sąsiadowice-Соседовичи } \\
\text { Rogóźno-Рогозное } \\
\text { Nichowice--Ниговичи }\end{array}$ & 2 objects \\
\hline Polish into Ukrainian & 241 & - & $\begin{array}{c}40 \text { objects } \\
\text { Examples: } \\
\text { Siedliska-Oceля } \\
\text { Błożew Dolna-Нижне }\end{array}$ & $\begin{array}{c}69 \text { objects } \\
\text { Examples: } \\
\text { Krakowiec-Краковець } \\
\text { Szutowa-Шутова }\end{array}$ & $\begin{array}{c}124 \text { objects } \\
\text { Examples: } \\
\text { Myślatycze-Мишлятичi } \\
\text { Chorośnica-Хоросниця } \\
\text { Wojkowice-Вуйковичі }\end{array}$ & 8 objects \\
\hline Russian into Ukrainian & 225 & 41 objects & $\begin{array}{c}5 \text { objects } \\
\text { Examples: } \\
\text { Хоросниса-Берегове }\end{array}$ & $\begin{array}{c}93 \text { objects } \\
\text { Ехатples: } \\
\text { Краковец-Краковець } \\
\text { Годыни-Годині } \\
\text { Вуйковичи-Вуйковичі }\end{array}$ & $\begin{array}{c}86 \text { objects } \\
\text { Examples: } \\
\text { Глубокая-Глибока } \\
\text { Твержа-Твіржа } \\
\text { Рогозна-Рогізно }\end{array}$ & - \\
\hline
\end{tabular}




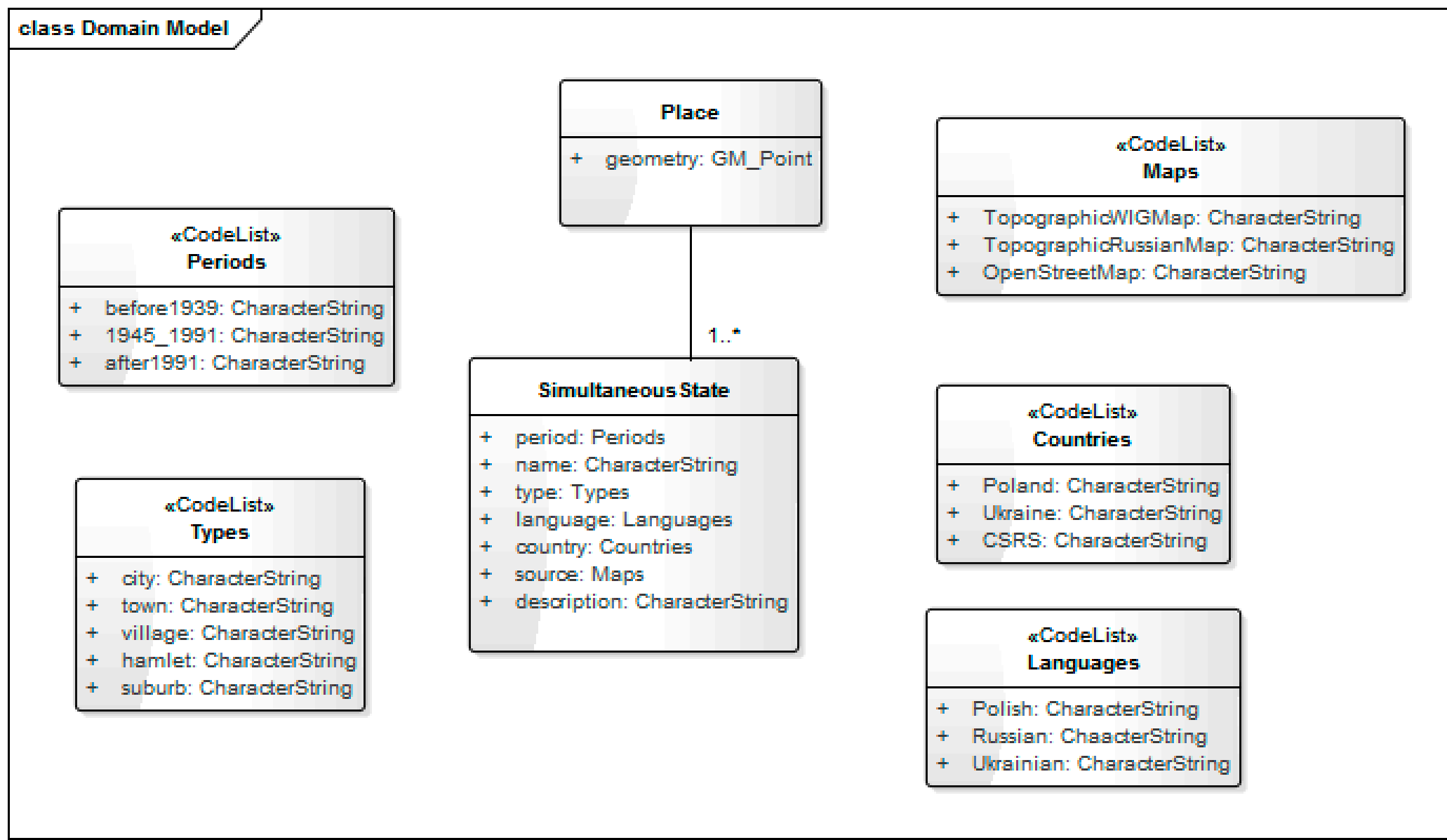

Figure 6. An UML (Unified Modeling Language) class diagram describing the concept of spatio-temporal database structure (source: own study). 


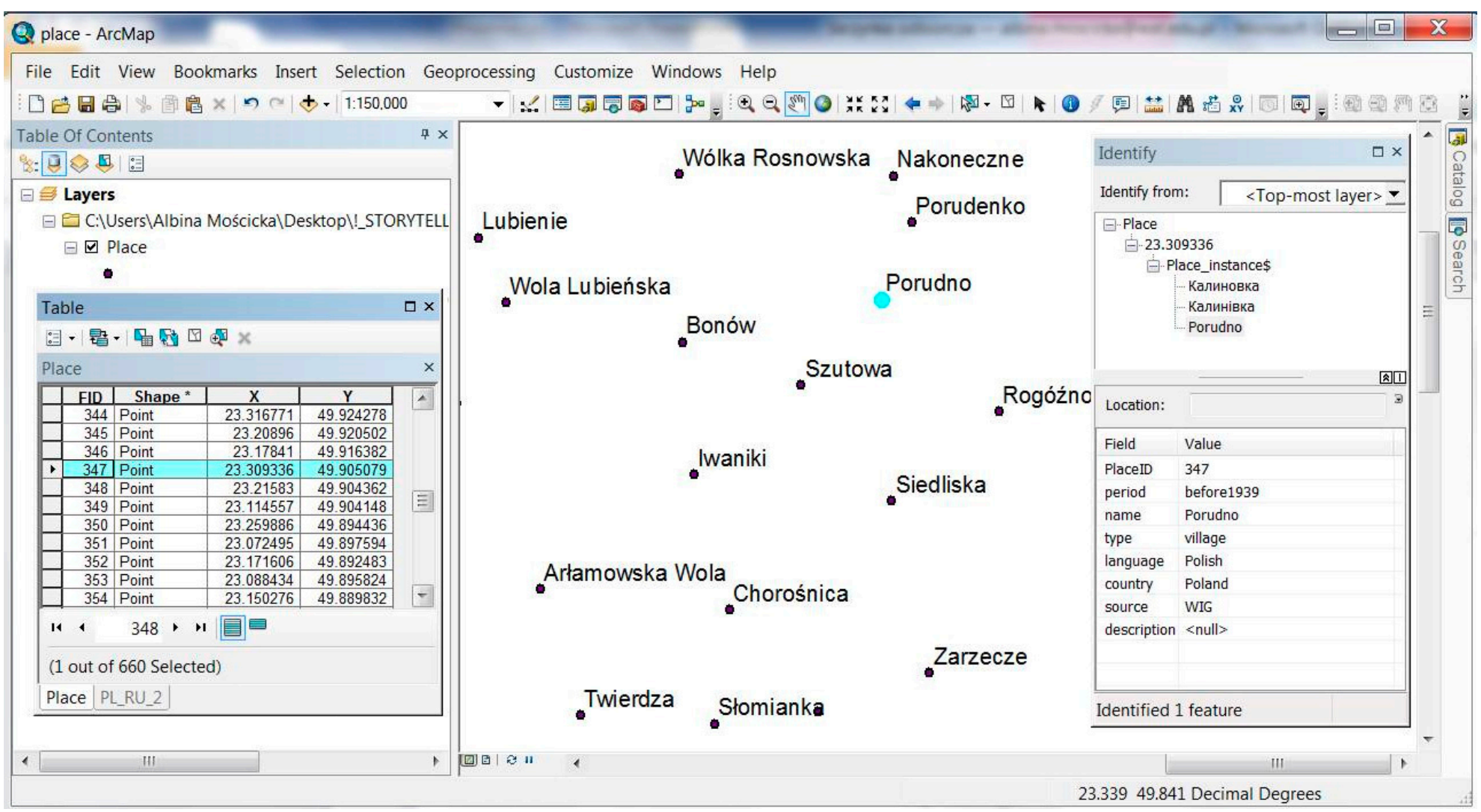

Figure 7. Implementation of the database in ArcGIS (source: own study). 


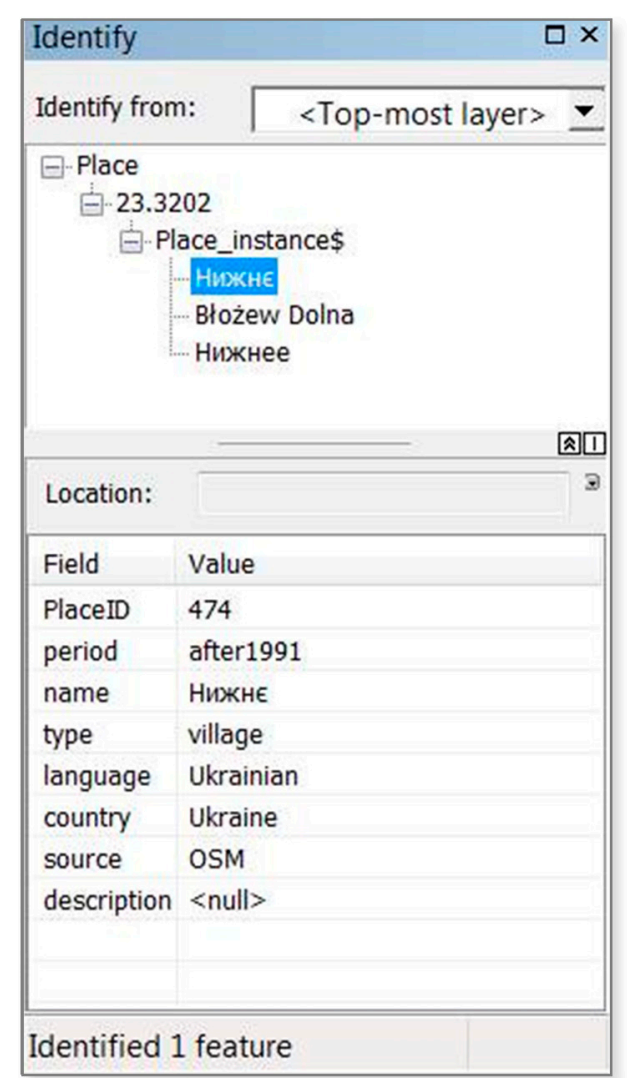

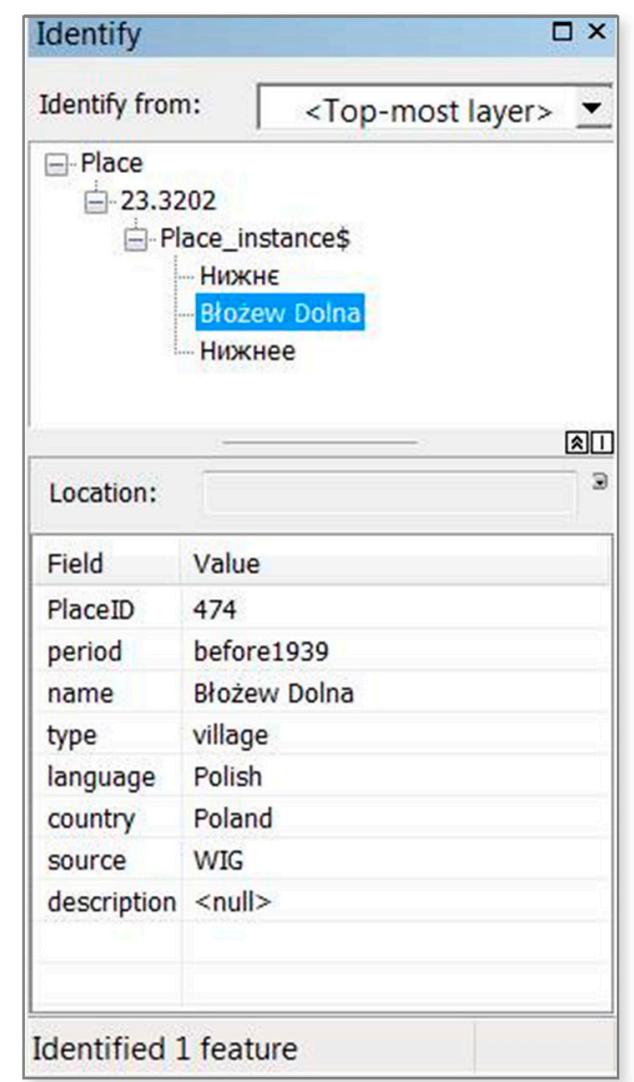

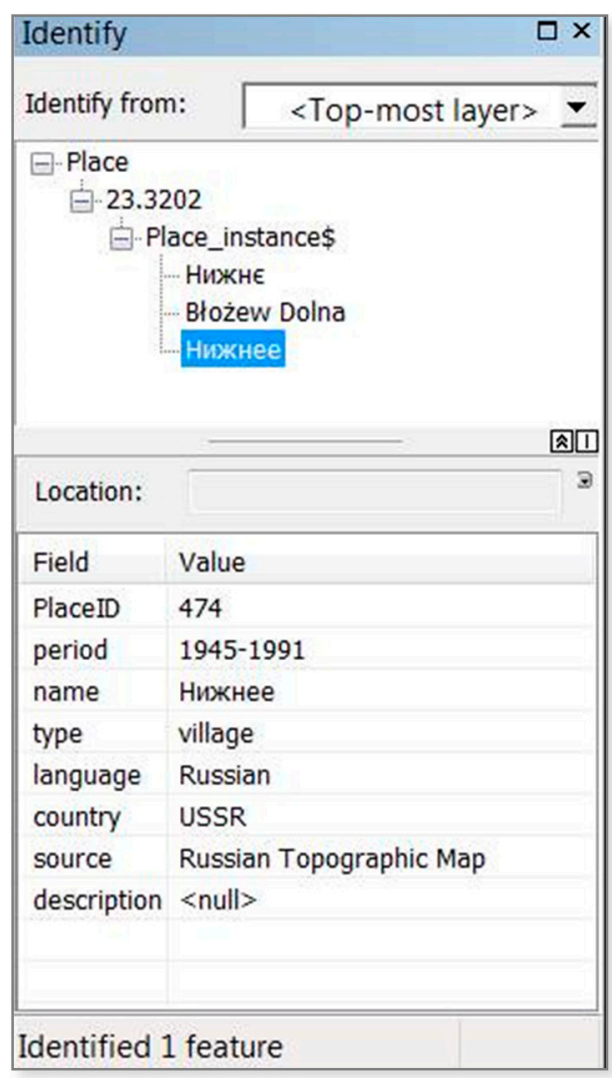

Figure 8. Simultaneous states of the selected locality (object instances) (source: own study). 

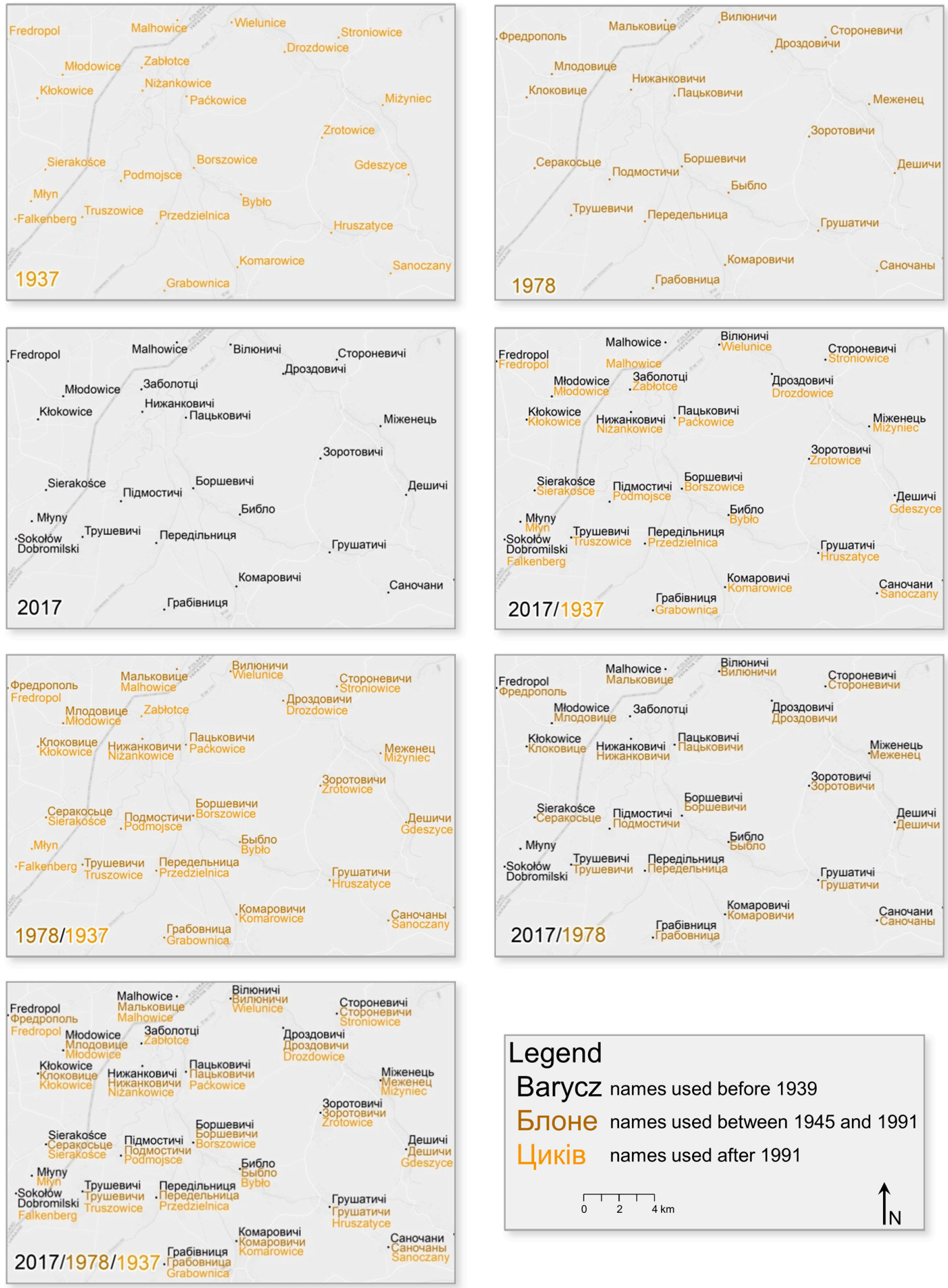

Figure 9. Backgrounds using names for one or few selected time periods (source: own study).

\section{Discussion}

In the research, WIG and OSM maps were used to compare pre-war and contemporary names in this part of test area, which covers the territory of current Poland. It was noticed that 177 out of 215 names of the Polish side of the current border, (more than 82\%) have not changed. Only 25 names are completely different between Polish (before 1939) and Polish (present OSM) maps (just over 11\%, e.g., Dmytrowice changed to Olszynka). Some names have been changed by abbreviation or elongation (respectively: two and four names, e.g., Parcelacja Boratyn changed to Parcelacja, Widna changed to 
Widna Góra), and, finally, seven places do not exist anymore (e.g., Stary Kalinów). A list of changes in Polish names together with examples is presented in Table 1.

As a result of the analysis, it was found that the rules for name swapping can be classified into four main groups. The first group contains names that have been completely changed. They are not based on the previous names in any way ("other name" in Table 2). There are 35 such names that have changed between Polish (before 1939) and Russian (1945-1991) maps (e.g., Porudno changed in Калиновка, Słomianka changed in Хоросниса etc.), 40 names have changed between Polish (before 1939) and Ukrainian (present OSM) maps (e.g., Siedliska changed to Оселя, Błożew Dolna changed to Нижнє) and five names have changed between Russian (1945-1991) and Ukrainian (present OSM) maps (e.g., Хоросниса changed in Берегове). In 10 cases, it was difficult to attribute name changes to any specific rules, but this did not affect the change from Russian to Ukrainian. This might result from the close relationship between these languages.

The second group are places whose names have been changed using transliteration. After 1945, when Polish names were changed into Russian, 85 names were changed using this rule (e.g., Tapin changed in Тапин). In the past, there were no direct name changes from Polish to Ukrainian, but the analysis of names in these languages showed that 69 names were changed using transliteration (e.g., Szutowa-Шутова), while the same applied to as many as 93 names changed from Russian into Ukrainian (e.g., Вуйковичи changed to Вуйковичi). The third group of changes refers to places whose names were changed based on transcription. Changes between Polish and Russian language on the basis of transcription refer to 100 names (e.g., Tamanowice-Тамановичи). The rules of these changes are presented in Table 2. Transcription was also used to change 124 Polish names into Ukrainian (e.g., Chorośnica-Хоросниця) and to change 86 names from Russian into Ukrainian (е.g., Заречье-Заріччя). The last group are names that are difficult to assign to any unambiguous change rules. There are two such names after changing Polish into Russian and eight after changing Polish into Ukrainian.

Since all three analyzed languages are Slavic languages, the place names used are very similar in their wording. However, for people who do not know the Cyrillic alphabet (alphabetical writing, used to write East Slavonic languages), it is virtually impossible to read the names. The principles of transcription and transliteration from Cyrillic to Latin are widely known [33] and available, while Latin letter/characters are rarely found in Cyrillic, which may cause additional problems in exchanging names in the analyzed languages. The existing Latin alphabet converters to the Cyrillic alphabet do not work properly [34], which makes it difficult to set the rules for creating names from WIG maps on OSM. The example of such situation can be presented on the basis of Ukrainian name Циків (before 1939 Polish village Cyków), which can be written as:

- Cikìv—based on the rules from the latest Polish standard [33];

- Cykiv—based on the transliteration from the pre-existing Polish standard [35]; and,

- Tsykiv—based on the transliteration from Ukrainian into English, adopted and disseminated in Ukraine.

In the spatio-temporal database structure (Figure 6) it was assumed that each place (class: Place) consists of many different states of the object, depending on the time period (class: SimultaneousState). Each object state is described by a set of attributes, including: name (attribute: name) existing in a given period of time (attribute: period), as well as the language (attribute: language) and country (attribute: country) in which the name exists. The type of object is also provided (attribute: type) and the source of information about the given name is specified (attribute: source). Most of the attributes are defined in the form of code lists containing admissible attribute values (code lists: Periods, Types, Languages, Countries, Maps). The above structure allows for selecting the state of the object (object's properties) in a given period of time, creating historical background map and presenting the story in the adequate historical context. 
The proposed database structure is the starting point for its development and consideration of further forms of place names. There was no such case in the test area, but there are some well-known areas in Poland, where names in a language other than official Polish language are used in one territory, due to large concentrations of national minorities. On the Ukrainian border, due to the "Vistula Action" (Akcja Wisła, 1947-1950, displacements of 140,000 Ukrainian and other nationality people from those regions to the area of present western and northern Poland), the Ukrainian language is not used in parallel with the Polish language. However, such a situation occurs on the Polish-Lithuanian borderland, in Silesia (south-western part of the country) or in Kashubia (in Pomerania region, west of Gdańsk). In these areas, names in national languages are used simultaneously with Polish names. The database has been designed so as to accommodate such solutions, e.g., as additional states of the same object in the same time period. What is more, it is advisable to conduct further research in this direction and identify further cases of parallel or alternative use of different names in one area.

In the research, the maps were used as an obvious and easily available source of data about the towns. However, they are not the only available source of data about names used in the past. Other types of registers, such as phone books, tax books, parish registers, etc., are also invaluable here. They provide enormous data resources that enable linking data from the past with the present geographical space, not only in the context of place names. They also enable to provide reference to the space, for example, people who lived in those times, or companies, and institutions that functioned in the past. Such registers are a source of very detailed data. Their use creates the premises for the development of the proposed database to a higher level of detail, for example to the city level, its streets, and even individual address numbers. Increasing the resolution in time and space, they can clearly show when and how the changes in names of persons or companies spread over the space. This also involves challenges in the spatial and temporal visualization of this type of data and phenomena as well as the development of such a database. It would undoubtedly be extremely time-consuming, but the cognitive and educational value would certainly be invaluable. What is more, the inclusion of this kind of information into the spatial database, whose content can be visualized on the maps, is certainly a more effective information message.The research included only places and their names, but the proposed structure provides an opportunity to develop the database by adding new elements, such as roads, forests, rivers, etc., and finally to collect the complex historical background content. Moreover, in the research changes in places location were not analyzed. It seems interesting to continue research in this direction and to extend the database also with aspects related to the changes of places location. Villages can combine, while developing cities not only increase their surface, but also absorb suburban villages. The database structure allows to enable variable location data as consecutive states of objects over time. What's more, this location can be considered at different levels of detail-the place can be represented as a point or as an area. It means that possible future research can go in different directions, finally resulting in the advanced spatio-temporal database, which would be invaluable source of reference data for historical storytelling.

The biggest problem in spatio-temporal data development seems to be the need to collect millions of pieces of information about places together with their historical properties. A lot of such data are now collected in many different gazetteers. The only problem is that they are scattered around the world, are related to limited specific areas and are not time-related. The most useful could be GeoNames [32], which contain a lot of names in different languages, together with historical names, but they are not connected with the times in which they existed. The interesting issue is whether it would be possible to use social networking sites to develop such a project. The unexpected strength of international communities has already proved invaluable in many huge projects. In any case, it seems necessary to develop such solutions through interdisciplinary teams combining IT specialists, historians, and cartographers. Only then can the results be considered as a comprehensive, professional, and useful solution. 


\section{Conclusions}

The proper understanding of thematic data (story) presented in geographical space requires an adequate background. This background is understood as a general geographic element, which defines the context in which these thematic data occur. There is no problem when thematic data are related to the present geographical space; they are presented on a background which contains actual elements of geographic space. A more complicated situation occurs when phenomena or events from the past are presented on maps. The current access to a number of historical data sources results in the development of ways and methods of presenting the past, including not only the use of traditional maps, but also, multimedia maps, interactive maps, and animated maps. They are quite often presented in relation to present environment, what can result in their incorrect or incomplete understanding.

The changes in geographical space, mainly in the place names, usually take place when changing political borders. It results in changes to all of the names that exist in the given territory. Therefore, the presentation of historical events that happened in the cross-border area meets certain complex problems related to the reference data for such events. The proposed spatio-temporal database, whose structure is dedicated to the places with names variable over time, can be helpful in such situations and can result in a more effective presentation of historical stories.

Acknowledgments: The research was carried out as part of the statutory work "Spatio-temporal characteristics of data and geographic objects in the context of their effective use" realized in years 2015-2018 at the Military University of Technology in Warszawa, Poland.

Author Contributions: Albina Mościcka designed the study; Marta Kuźma performed the experiments; Albina Mościcka and Marta Kuźma analyzed the data; Albina Mościcka and Marta Kuźma wrote the paper.

Conflicts of Interest: The authors declare no conflict of interest.

\section{References}

1. Mościcka, A. GIS Technology as an Alternative Way of Access to Historical Knowledge. In Routledge Studies in Library and Information Science; Digital Scholarship: New York, NY, USA, 2009; pp. 72-91.

2. Cameron, E. New geographies of story and storytelling. Prog. Hum. Geogr. 2012, 36, 573-592. [CrossRef]

3. Kerski, J.J. Geo-awareness, Geo-enablement, Geotechnologies, Citizen Science, and Storytelling: Geography on the World Stage. Geogr. Compass 2015, 9, 14-26. [CrossRef]

4. Levin, N.; Kark, R.; Galilee, E. Maps and the settlement of southern Palestine, 1799-1948: An historical/GIS analysis. J. Hist. Geogr. 2010, 36, 1-18. [CrossRef]

5. Padilla, C. Historical GIS: Mapping the past to understand the future. Online 2008, 32, 32-35.

6. Morillas Torné, M. Creation of a Geo-Spatial Database to Analyse Railways in Europe (1830-2010). A Historical GIS Approach. J. Geogr. Inf. Syst. 2012, 176-187. [CrossRef]

7. Simion, G.; Mareci, A.; Zaharia, F.; Dumitru, R. Historical GIS: Mapping the Bucharest geographies of the pre-socialist industry. Hum. Geogr. 2016, 10, 2067-2284. [CrossRef]

8. Roshannejad, A.A.; Kainz, W. Handling Identities in Spatio-Temporal Databases. Proc. ACSM/ASPRS 1995, 4, 119-126.

9. Tamas, A.; Roddick, J.F. Survey of Spatio-Temporal Databases. GeoInformatica 1999, 3, 61-99. [CrossRef]

10. Fan, Y.T.; Yang, J.Y.; Zhu, D.H.; Wei, K.L. A time-based integration method of spatio-temporal data at spatial database level. Math. Comput. Model. 2010, 51, 1286-1292. [CrossRef]

11. Fan, Y.; Yang, J.; Zhu, D.; Zhang, C. Research on the efficiency of querying historical data with the spatio-time data integration method. Math. Comput. Model. 2011, 54, 912-918. [CrossRef]

12. Wu, H.; Liu, Z.; Zhang, S.; Zuo, X. A spatio-temporal data model for road network in data center based on incremental updating in vehicle navigation system. Chin. Geogr. Sci. 2011, 21, 346-353. [CrossRef]

13. Le, H.H.; Gabriel, P.; Gietzel, J.; Schaeben, H. An object-relational spatio-temporal geoscience data model. Comput. Geosci. 2013, 57, 104-115. [CrossRef]

14. Böhlen, M.H.; Jensen, C.S. Spatio-Temporal Database Management: International Workshop STDBM'99 Edinburgh, Scotland, September 10-11 1999 Proceedings; Springer Science \& Business Media: Berlin/Heidelberg, Germany, 1999; Volume 1678; 254p. 
15. Harbelot, B.; Arenas, H.; Cruz, C. LC3: A spatio-temporal and semantic model for knowledge discovery from geospatial datasets. Web Semant. Sci. Serv. Agent. World Wide Web 2015, 35, 3-24. [CrossRef]

16. Madraky, A.; Othman, Z.A.; Hamdan, A.R. Hair-oriented data model for spatio-temporal data representation. Exp. Syst. Appl. 2016, 59, 119-144. [CrossRef]

17. Mahmood, N.; Burney, M.A.; Rizwan, K.; Shah, A.; Nadeem, A. Building spatio-temporal database model based on ontological approach using relational database environment. Mehr. Univ. Res. J. Eng. Technol. 2017, 36, 891-900. [CrossRef]

18. Stefanakis, E. Modelling the history of semi-structured geographical entities. Int. J. Geogr. Inf. Sci. 2003, 17, 517-546. [CrossRef]

19. Weaver, C.; Fyfe, D.; Robinson, A.; Holdsworth, D.; Peuquet, D.; MacEachren, A.M. Visual exploration and analysis of historic hotel visits. Inf. Visualizat. 2007, 6, 89-103. [CrossRef]

20. Jacquez, G.M.; Goovaerts, P.; Rogerson, P. Space-time intelligence systems: Technology, applications and methods. J. Geogr. Syst. 2005, 7, 1-5. [CrossRef]

21. Sengupta, R.; Yan, C. A Hybrid Spatio-Temporal Data Model and Structure (HST-DMS) for Efficient Storage and Retrieval of Land Use Information. Trans. GIS 2004, 8, 351-366. [CrossRef]

22. Moscicka, A. Europeana Data Model in GIS for Movable Heritage. Geografie 2015, 120, 527-541.

23. Perkmann, M. Cross-border regions in Europe: Significance and drivers of regional cross-border co-operation. Eur. Urban Reg. Stud. 2003, 10, 153-171. [CrossRef]

24. Medeiros, E. (Re)defining the concept of Euroregion. Eur. Plan. Stud. 2011, 19, 141-158. [CrossRef]

25. Medeiros, E. Euro-Meso-Macro: The new regions in Iberian and European Space. Reg. Stud. 2013, 47, 1249-1266. [CrossRef]

26. Dühr, S.; Nadin, V. Europeanization through transnational territorial cooperation? The case of INTERREG IIIB North-West Europe. Plan. Pract. Res. 2007, 22, 373-394. [CrossRef]

27. Kuhn, W. Core concepts of spatial information for transdisciplinary research. Int. J. Geogr. Inf. Sci. 2012, 26, 2267-2276. [CrossRef]

28. Hahmann, S.; Burghardt, D. How much information is geospatially referenced? Networks and cognition. Int. J. Geogr. Inf. Sci. 2013, 27, 1171-1189. [CrossRef]

29. Janowicz, K. The Role of Space and Time For Knowledge Organization on the Semantic Web. Semant. Web 2010, 1, 25-32. [CrossRef]

30. The Gazetteer of British Place Names. Available online: https://www.gazetteer.org.uk/ (accessed on 1 December 2018).

31. GeoNames, National Geospatial-Intelligence Agency. Available online: http://geonames.nga.mil/ namesgaz/ (accessed on 1 December 2018).

32. GeoNames. Available online: http://www.geonames.org (accessed on 1 December 2018).

33. International Organization for Standardization. Information and Documentation-Transliteration of Cyrillic Characters into Latin Characters-Slavic and Non-Slavic Languages (The Principles of Transcription and Transliteration from Cyrillic to Latin Are Widely Known-Norma); ISO: Geneva, Switzerland, 1995.

34. Cyrillic to Latin Converter (Przełożnik Miroszewiczny-Konwerter Alfabetu Łacińskiego na Cyrylicę). Available online: http:/ / brugia.ayz.pl/cyrylica/ (accessed on 1 December 2018).

35. International Organization for Standardization. Documentation-Transliteration of Slavic Cyrillic Characters into Latin Characters; ISO: Geneva, Switzerland, 1986.

(C) 2018 by the authors. Licensee MDPI, Basel, Switzerland. This article is an open access article distributed under the terms and conditions of the Creative Commons Attribution (CC BY) license (http:/ / creativecommons.org/licenses/by/4.0/). 